\title{
MAKNA DIRI PENYANDANG OLIGODAKTILI
}

\author{
Sulaeman ${ }^{1}$, Deddy Mulyana ${ }^{2}$ \\ ${ }^{1}$ Fakultas Ushuluddin dan Dakwah, Jurusan Jurnalistik Islam, Institut Agama Islam Negeri Ambon \\ Jl. Dr. H. Tarmidzi Taher, Kebun Cengkeh, Batumerah Atas, Ambon, Maluku, 97128, Indonesia \\ ${ }^{2}$ Fakultas Komunikasi, Jurusan Jurnalistik, Universitas Padjadjaran \\ Jl. Raya Bandung - Sumedang Km. 21, Jatinangor, Sumedang, Jawa Barat, 45363, Indonesia \\ No.Telp./HP: ${ }^{1} 085322526106,{ }^{2} 08157121250$ \\ E-mail: ${ }^{1}$ sulaeman@iainambon.ac.id, ${ }^{2}$ deddymulyana96@yahoo.com
}

Naskah diterima tanggal 20 November 2019, direvisi tanggal 24 Desember 2019, disetujui tanggal 22 Januari 2019

\section{SELF-MEANING WITH OLIGODACTYLY SUFFERERS}

\begin{abstract}
Indonesia is a developing country, a population of more than a quarter of a billion people with a variety of health problems, including oligodactyly sufferers in the Village of Ulutaue, Bone Regency, South Sulawesi. They are different from normal people in the surrounding environment. The symbol "self-identity" is given by a normal person in everyday life. The purpose of this research is to find out and explain the self-meaning oligodactyly sufferers. The method of this research is communication phenomenology, examines the experiences with communication and interaction of natural oligodactyly on the surrounding environment. This research uses a qualitative approach based on the subjective interpretive techniques of data collection through interviews and participatory observations with complementary data based on the perspective of the social action and symbolic interaction. This research involves fifteen subjects with ten men and five women selected by purposive. The results of this research categories such as physical abnormalities and form a physical organ. The selfmeaning of physical abnormalities on the fingers, such as spirit-self, optimistic of abandonment, despair, closed, and lazy. The self-meaning of forms a physical organ with oligodactyly sufferers since birth, such as inflicting shame-self, deserve our pity, willpower hard work, patience, and a driving passion.
\end{abstract}

Keywords: self-meaning, oligodactyly, physical abnormalities, forms a physical organ.

\begin{abstract}
Abstrak. Indonesia merupakan negara berkembang, populasi penduduk lebih dari seperempat milliar orang dengan keberagaman masalah kesehatan, termasuk penyandang oligodaktili di Kampung Ulutaue, Kabupaten Bone, Provinsi Sulawesi Selatan. Mereka berbeda dengan orang normal di lingkungan sekitarnya. Memiliki simbol "identitas diri" diberikan oleh orang normal dalam kehidupan sehari-hari. Tujuan penelitian untuk menemukan dan menjelaskan mengenai makna diri penyandang oligodaktili. Metode penelitian yang digunakan adalah fenomenologi komunikasi, mengkaji pengalaman komunikasi dan interaksi penyandang oligodaktili yang dialami di lingkungan sekitarnya. Penelitian ini menggunakan pendekatan kualitatif berdasarkan interpretatif subjektif dengan teknik pengumpulan data melalui wawancara dan pengamatan partisipatif dengan data penunjang berdasarkan perspektif tindakan sosial dan interaksi simbolik. Penelitian ini melibatkan 15 subjek dengan sepuluh laki-laki dan lima perempuan dipilih secara purposif. Hasil penelitian ini dikategorikan makna diri kelainan fisik dan bentuk organ fisik. Makna diri kelainan fisik pada jemari tangan atau jemari kaki, seperti diri pasrah, semangat, optimis, putus asa, tertutup, dan malas. Makna diri bentuk organ fisik penyandang oligodaktili sejak lahir, seperti diri menimbulkan rasa malu, pantas dikasihani, kemauan kerja keras, sabar, dan pendorong semangat.
\end{abstract}

Kata kunci: makna diri, oligodaktili, kelainan fisik, bentuk organ fisik. 


\section{PENDAHULUAN}

Konsep kesehatan dapat dipahami secara beragam dengan lintas budaya, dengan perbedaan cara pandang terhadap keadaan sakit dan penyakit serta faktor penyebabnya. Perbedaan cara pandang dalam memahami kesehatan dan keadaan sakit terkait dengan budaya, agama, suku, nilai, keyakinan, dan keadaan sosial-ekonomi. Keragaman cara pandang kesehatan, keadaan sakit, dan penyakit dalam model kesehatan meliputi model biomedis, personalistik, dan naturalistik. Paradigma biomedis, termasuk penyandang oligodaktili, bukan hanya dilihat fenomena keterbatasan jemari tangan dan jemari kaki saja, namun harus melalui pendekatan biopsikososial dalam model komunikasi transaksional dalam memaknai diri sebagai penyandang oligodaktili.

Landasan filosofis penyandang oligodaktili memiliki kelayakan untuk dijadikan kerangka komunikasi kesehatan bagi penyandang oligodaktili kini dan mendatang. Filosofis komunikasi kesehatan ini memiliki faktor body, mind, soul, dan social, tidak hanya proses terjadinya penyakit tetapi emosi dan perasaan individu mengenai permasalahannya, bagaimana penyandang oligodaktili memandang dirinya dan kaitannya dengan di lingkungan sekitarnya. Dalam perspektif sosial, suatu keadaan sakit yang boleh jadi memengaruhi kondisi psikologisnya dan interaksi lingkungan di sekitarnya. Pandangan Clift dan Freimuth dalam Mulyana \& Sulaeman (2016) menjelaskan bahwa konsep komunikasi kesehatan mengenai penyandang oligodaktili adalah untuk mendukung dan mempertahankan kebiasaannya guna mencapai hasil peningkatan kesehatan aspek biomedis, personalistik, dan naturalistik.

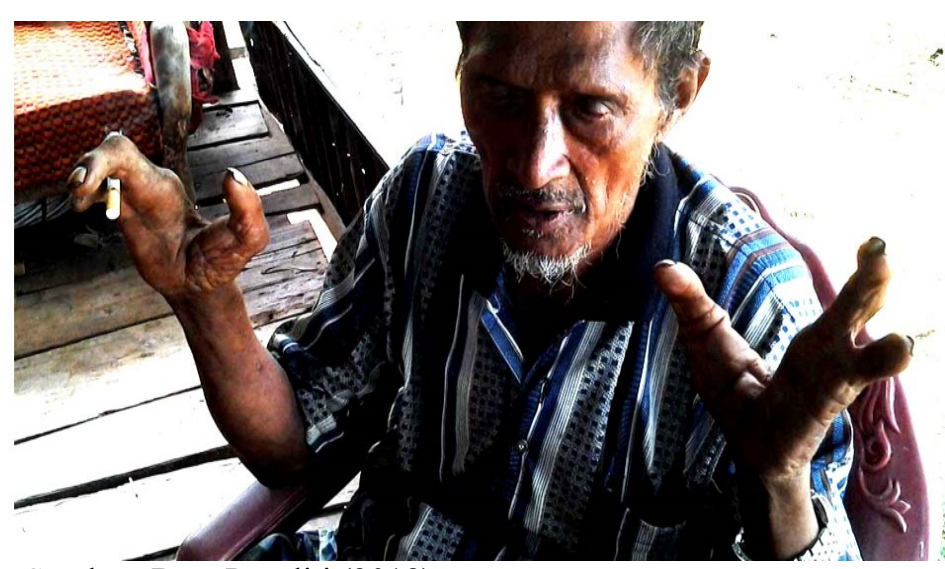

Sumber: Data Peneliti (2018)

Gambar 1. Jemari Tangan Penyandang Oligodaktili

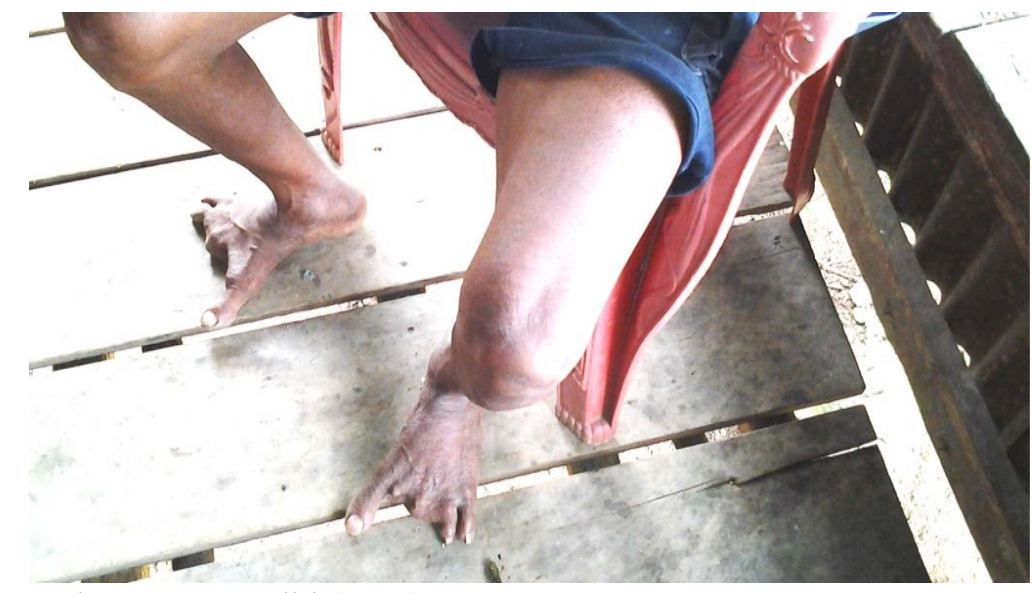

Sumber: Data Peneliti (2018)

Gambar 2. Jemari Kaki Penyandang Oligodaktili 


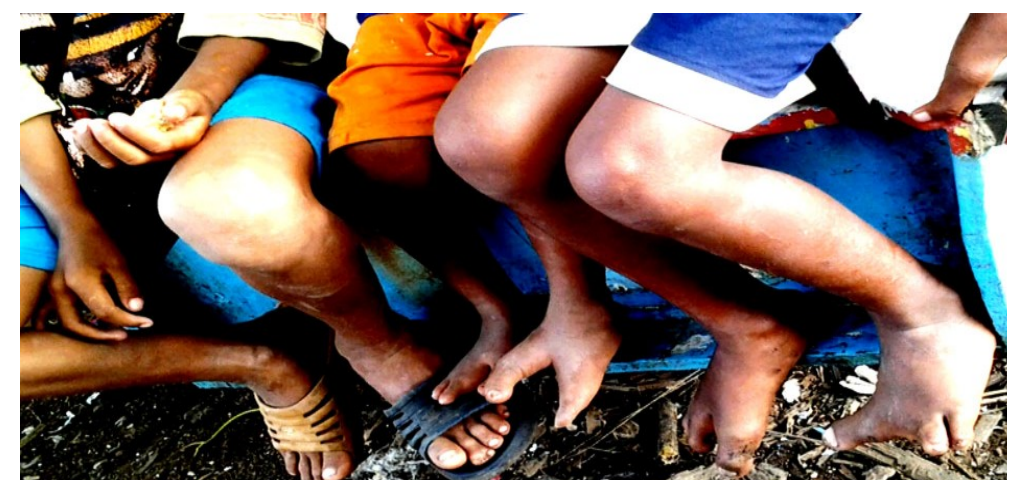

Sumber: Data Peneliti (2018)

Gambar 3. Jemari Tangan dan Jemari Kaki Penyandang Oligodaktili

Penyandang oligodaktili yang tinggal di Kampung Ulutaue pada saat penelitian dilakukan, kampung ini dikaitkan kampung dihuni orang-orang "lobster-claw syndrome," meskipun banyak orang normal tinggal di sekitar lingkungan kampung tersebut. Kampung Ulutaue dikonstruksi media televisi sebagai "kampung manusia kepiting," menyebabkan beberapa masyarakat di kampung melakukan perlawanan, termasuk beberapa penyandang oligodaktili. Perlakuan penerimaan diskriminatif merupakan gambaran dari stigma yang berhubungan dengan stereotip masyarakat yang diberikan sebagai penjulukan (Sulaeman, 2018). Di antara mereka menyadari bahwa media televisi mengonstruksi kampung semata-mata berorientasi pada keuntungan tanpa melihat fisik, psikologi, dan kondisi ekonomi penyandang oligodaktili. Atribut inilah yang kemudian dapat membuatnya menjadi berbeda dengan orang lain dan membawanya ke dalam stigmatisasi seperti dikemukakan (Goffman, 1973), stigma seringkali dimunculkan dalam kelainan kulit dan penyandang cacat fisik. Stigma ini akan membawa aib memalukan bagi penyandang oligodaktili dan mereka akan menjadi rendah diri, malu, dan takut karena keterbatasan jemari tangan dan jemari kaki dialami.

Penyandang oligodaktili memiliki fenomena pengalaman hidup yang tidak mudah untuk dijalani. Mengingat berbagai pergumulan batin yang kompleks dalam menghadapi kondisi fisik yang berbeda dan dianggap kurang jika dibandingkan orang "normal". Hal tersebut merupakan permasalahan unik yang sulit dirasakan oleh individu yang memiliki kondisi fisik dan mental normal. Sebagai simbol "identitas diri" yang diberikan oleh orang normal pada para penyandang oligodaktili dengan julukan "jemari bertangkai, manusia jari kepiting, dan atau keluarga bertangan kepiting" menular, makanan menjijikkan yang dapat melemahkan diri dan merasakan dirinya "seperti apapun," menjadi landasan pemunculan makna subjektif dari setiap tindakan dalam mengontruksi dirinya.

Keunikan penyandang oligodaktili menjadi alasan penting pelaksanaan penelitian ini dengan menggunakan perspektif Weber dalam Sulaeman \& Irta (2017), tindakan sosial merupakan interaksi simbolik antara kesadaran individu dan kesadaran invidu lainnya dalam kebersamaan hidup (Mulyana, 2016). Menggunakan teori interaksi simbolik dari Blummer dalam Sulaeman \& Muhammad (2018) tindakan individu didasarkan pada pemahaman mereka mengenai orang, objek, dan atau lingkungan mereka yang dihadapi, dan mereka dapat mengubah tindakannya berdasarkan interpretasi mereka atas orang lain (Sulaeman \& Muh, 2015). Peneliti bermaksud mengeksplorasi bagaimana kesadaran penyandang oligodaktili memaknai dirinya. Sebagaimana dikatakan (Marks, D.F; Michael, F; Brian, E. \& Carla, 2000), "Cerita orang mengenai kesehatan dan keadaan sakit itu sendiri adalah tema menarik dan mencerahkan untuk diteliti".

Berdasarkan perspektif interpretatif, penyandang oligodaktili dapat memberikan makna tertentu mengenai apa yang dialami pada dirinya. Perspektif ini dianggap sesuai dan lebih holistik untuk meneliti keunikan diri penyandang oligodaktili. Fokusnya di 
sini bukan pada aspek kesehatan dan keadaan sakit, yang dipahami secara objektif berdasarkan pengukuran ilmiah dan atau medis, melainkan pengalaman mengenai apa dialami pada dirinya sebagai penyandang oligodaktili secara subjektif.

Realitas sosial yang dialami penyandang oligodaktili membutuhkan pemahaman mendasar terkait diri yang memiliki keterbatasan jemari tangan dan jemari kaki terbelah menjadi dua hingga mirip capit kepiting sejak lahir di antara realitas yang melingkupi dirinya yang dilakukan pada orang lain. Dengan pemahaman sebagai subjek dan bukan sebagai objek melalui komunikasi transaksional dengan model komunikasi biopsikososial. Penelitian ini dilakukan dengan tujuan untuk menemukan dan menjelaskan mengenai penyandang oligodaktili yang memaknai dirinya memiliki keterbatasan jemari tangan dan jemari kaki sejak lahir berbeda dengan orang normal di lingkungan sekitarnya.

Penyandang oligodaktili dari sisi subjek, menggambarkan apa yang mereka rasakan, apa yang mereka pikirkan, dan apa yang mereka lakukan. Penelitian ini menarik dilakukan dengan alasan dalam diri penyandang oligodaktili bukan hanya memiliki pengalaman diri dengan keterbatasan fisik, namun memiliki makna diri secara verbal maupun non verbal dalam setiap interaksi sosial yang dilakukan di lingkungan sekitarnya dan simbol-simbol perlakuan penerimaan dirinya. Alasan lainnya, penyandang oligodaktili tetap menerima perlakuan identitas dirinya sebagai individu yang memiliki keterbatasan fisik yang berbeda dengan orang normal. Penelitian ini diharapkan dapat memperkaya kajian pendekatan penelitian kualitatif berdasarkan tindakan sosial, fenomenologi, dan interaksi simbolik. Dengan beberapa kategori makna diri yang muncul dari kajian fenomena sosial ini diharapkan akan memperkaya dan mengembangkan teori komunikasi, terutama komunikasi penyandang oligodaktili yang memperkuat landasan ilmiah dalam pengembangan ilmu komunikasi serta pengembangan akar ilmu komunikasi. Penelitian ini diharapkan dapat menjadi rujukan bagi masyarakat akademisi untuk memahami makna sebagaimana dikonstruksi penyandang oligokdatili mengenai diri yang berbeda dengan orang normal.

Berdasarkan paparan yang telah dijelaskan, maka aksiologis penelitian ini memiliki nilai kebaruan dilihat dari segi pemaknaan terhadap keterbatasan fisik penyandang oligodaktili, dan dapat memberikan pengetahuan untuk memaknai diri penyandang oligodaktili, sehingga krisis kesadaran masyarakat khususnya orang normal terhadap pentingnya memahami kompetensi kesadaran sosiologi penyandang oligodaktili yang tidak berbeda dan atau melebihi kompetensi orang normal. Tidak mudah bagi masyarakat di luar disabilitas untuk menghormati dan menghargai perasaan diri penyandang oligodaktili. Ini disebabkan adanya perlakuan penerimaan ketidaknyamanan yang berbeda dengan orang normal yang disertai dengan pemberian penjulukan, stigma, dan diskriminasi pada diri penyandang oligodaktili.

\section{LANDASAN KONSEP}

\section{Penelitian Terdahulu}

Adapun perbedaaan penelitian ini dilakukan dengan penelitian terdahulu tergambar pada Tabel 1.

Penyandang cacat dikategorikan pada derajat kecacatan pada tingkat berat ringannya keadaan cacat disandang. Derajat kecacatan dianggap menghambat aktivitas sehari-hari, memunculkan perdebatan tersendiri mengenai batasan kondisi penyandang cacat. Kecacatan tidak hanya sebatas ketidakadaan ataupun ketidakberfungsian salah satu bagian tubuh yang dapat berpengaruh terhadap aktivitas fisik, namun secara lebih luas batasan cacat dikembangkan menjadi ketidakberfungsian yang diakibatkan oleh penyakit dan/atau kelainan fisik tertentu. 


\section{Tabel 1}

Perbedaan Hasil Penelitian Terdahulu dengan Penelitian Dilakukan

\begin{tabular}{|c|c|}
\hline Judul & 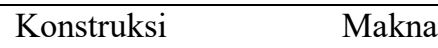 \\
\hline Penelitian & $\begin{array}{l}\text { Penyandang Filariasis (Studi } \\
\text { Fenomenologi tentang } \\
\text { Konstruksi Makna } \\
\text { Penyandang Filariasis dalam } \\
\text { Komunikasi Risiko Kesehatan } \\
\text { di Kabupaten Bandung. }\end{array}$ \\
\hline Penulis & $\begin{array}{lr}\text { (Hadisiwi, } & 2011 \text { ) } \\
\text { Unpublished } & \text { Doctoral } \\
\text { Dissertation } & \text { Padjadjaran } \\
\text { University. } & \end{array}$ \\
\hline $\begin{array}{l}\text { Deskripsi } \\
\text { Penelitian }\end{array}$ & $\begin{array}{l}\text { Penelitian ini terfokus pada } \\
\text { makna dirinya sebagai diri } \\
\text { yang pasrah, putus asa, tidak } \\
\text { menyerah dan makna diri } \\
\text { tidak sakit. Sebagian } \\
\text { penyandang filariasis sudah } \\
\text { tidak melanjutkan upaya } \\
\text { pengobatan medis dijalani. } \\
\text { Kemudian pengobatan massal } \\
\text { berhasil mengembangkan } \\
\text { konsep diri pada aspek positif } \\
\text { dan negatif. }\end{array}$ \\
\hline $\begin{array}{l}\text { Fokus } \\
\text { Penelitian }\end{array}$ & $\begin{array}{l}\text { Fokus penelitian ini diarahkan } \\
\text { kepada } \\
\text { Makna risiko penyakit dan } \\
\text { informasi risiko, serta konsep } \\
\text { diri pengobatan massal pada } \\
\text { penyandang filariasis. }\end{array}$ \\
\hline
\end{tabular}

Tujuan Penelitian

Untuk memahami makna yang dikonstruksi oleh penyandang filariasis tentang diri yang sakit, diri yang cacat, pengobatan, informasi filariasis dari berbagai sumber, pengetahuan tentang pengobatan massal dan konsep diri berdasarkan pengalaman.

Penelitian ini terfokus pada permasalahan pemaknaan kecacatan dan status atlet berprestasi, serta pengalaman komunikasi positif dan negatif atlet penyandang cacat dengan lingkungan yang dihasilkan dari interaksi dengan keluarga, lembaga, dan masyarakat.

Fokus penelitian ini mengenai makna kecacatan, status sebagai atlet berprestasi dan pengalaman komunikasi menurut sudut pandang atlet penyandang cacat berprestasi

Untuk memahami makna kecacatan, status sebagai atlet berprestasi dan pengalaman komunikasi menurut sudut pandang atlet penyandang cacat berprestasi.
Makna Diri Penyandang

Oligodaktili.

Sulaeman dan Deddy Mulyana (Desember 2017 April 2018)

Deskripsi penelitian ini menitik-beratkan kepada ketertarikan peneliti terkait makna diri penyandang oligodaktili yang memiliki keterbatasan pada jemari tangan dan jemari kaki yang berbeda dengan orang normal di lingkungan sekitarnya di Kampung Ululutaue Kabupaten Bone Provinsi Sulawesi Selatan.

Fokus penelitian ini adalah bagaimana penyandang oligodaktili memaknai dirinya memiliki keterbatasan jemari tangan dan jemari kaki sejak lahir berbeda dengan orang normal di lingkungan sekitarnya.

Untuk menggambarkan penyandang oligodaktili memaknai dirinya memiliki jemari tangan dan jemari kaki sejak lahir berbeda dengan orang normal di lingkungan sekitarnya.

Kualitatif, Fenomenologi Komunikasi

Kualitatif, Fenomenologi Komunikasi

Wawancara mendalam dengan para informan, observasi partisipatif, studi pustaka, dan studi dokumentasi.
Wawancara mendalam, observasi partisipan, studi pustaka, dan studi dokumentasi.
Wawancara mendalam,
observasi partisipan, studi pustaka dan studi dokumentasi dari berbagai sumber. 


\begin{tabular}{|c|c|c|c|}
\hline $\begin{array}{l}\text { dan } \\
\text { Persamaan } \\
\text { dengan }\end{array}$ & $\begin{array}{l}\text { ini adalah dari objek } \\
\text { penelitian dan permasalahan } \\
\text { diteliti sebagai fokus kajian. }\end{array}$ & $\begin{array}{l}\text { ini adalah dari aspek } \\
\text { permasalahan yang diteliti. } \\
\text { Persamaannya adalah metode }\end{array}$ & $\begin{array}{l}\text { adalah dari objek dan fokus } \\
\text { penelitian yang diteliti. } \\
\text { Persamaannya adalah metode }\end{array}$ \\
\hline $\begin{array}{l}\text { Penelitian } \\
\text { Terdahulu }\end{array}$ & $\begin{array}{l}\text { Persamaannya adalah metode } \\
\text { kualitatif dan pendekatan } \\
\text { fenomenologi. }\end{array}$ & $\begin{array}{l}\text { kualitatif dan pendekatan } \\
\text { fenomenologi. }\end{array}$ & $\begin{array}{l}\text { kualitatif dan pendekatan } \\
\text { fenomenologi. }\end{array}$ \\
\hline
\end{tabular}

Sumber: diolah dari berbagai sumber

Peraturan Pemerintah Nomor 36 Tahun 1980 tentang Usaha Kesejahteraan Sosial Penderita Cacat menyatakan bahwa penderita cacat adalah individu yang menurut ilmu kedokteran dinyatakan memiliki kelainan fisik atau mental yang merupakan rintangan atau hambatan baginya untuk melaksanakan kegiatan secara layak, terdiri dari cacat tubuh, cacat netra, cacat mental, cacat rungu wicara, dan cacat bekas penyandang penyakit kronis. Kategori penyandang cacat disempurnakan dengan keluarnya Undang-Undang Nomor 4 tahun 1997 tentang Penyandang Cacat, yang meliputi penyandang cacat fisik, cacat mental, penyandang cacat fisik dan mental, dan termasuk penyandang oligodaktili yang diistilahkan "hipodaktili".

Penyandang oligodaktili diistilahkan "hipodaktili," karena jari tangan dan kaki kurang yang tidak normal (Sulaeman, 2018). Penyandang oligodaktili memiliki keterbatasan kelainan fisik dan bentuk organ fisik pada jemari tangan dan jemari kaki yang lebih dari normal. Menurut Turnpenny, P.D., J.C.S. Dean, P. Duffty, J.A. Reid (1992) oligodaktili merupakan tanda atau gejala dari sindrom, termasuk poland sindrom dengan jenis dysmelia (kurangnya anggota badan). Poland sindrom sebagai kelainan cacat fisik sejak lahir, ditandai jemari tangan tidak normal yang lebih banyak dialami pada laki-laki daripada perempuan, disebabkan oleh gen. Oligodaktili dalam ilmu medis disebabkan oleh faktor genetika.

\section{Makna Diri}

Jika dilihat dari teori fenomenologi, setidaknya makna adalah "... is a certain way of directing one's gaze at an item of one's own experience" (Sulaeman \& Muh, 2015). Makna merupakan hasil dari suatu konstruksi, berkembang seiring pengalaman hidup subjek. Menurut Kuswarno dalam
Gabriella, E. A., Hanny H., \& Heru (2018) tujuan penelitian fenomenologi, adalah untuk menemukan makna dan hakikat dari pengalaman, bukan sekedar mencari penjelasan atau mencari ukuran-ukuran dari realitas. Makna penyandang oligodaktili akan berubah seiring perkembangan pengalaman yang dimiliki mengenai elemen dan menjadi bagian konstruksi kelainan fisik dan bentuk organ fisik.

Brown dalam Gabriella, E.A., Hanny H., \& Heru (2018) mendefinisikan makna sebagai kecenderungan untuk menggunakan atau bereaksi terhadap suatu bentuk bahasa. Dalam perspektif komunikasi berarti penafsiran atau pemahaman individu. Makna selalu mencakup banyak pemahaman secara bersama dimiliki individu. Makna penyandang oligodaktili sebagai “... the heart of perceiving, remembering, judging, feeling, and thinking...when we reflect upon something and arrive at its essence, we have discovered another major component of meaning" (Sulaeman \& Muhammad, 2018). Disebutkan pula bahwa “...without meaning we would not make choises, because the concept of choice would not be available to us" (Lindlof, 1995). Makna penyandang oligodaktili dibentuk dari penilaian dan tindakan diri yang memiliki kelainan fisik dan bentuk organ fisik yang berbeda dengan orang lain.

Menurut Mead terdapat konsep mengenai "diri," seperti juga Cooley mendefinisikan sebagai "suatu proses yang berasal dari interaksi sosial individu dengan orang lain" (Mulyana, 2018) dan bagi Mead dan Cooley, "diri" muncul karena komunikasi. Makna diri dibangun penyandang oligodaktili melalui interaksi dan komunikasi dengan lingkungan sekitarnya. Jika menggunakan pandangan Cooley mengenai makna diri, maka akan mempermudah pemahaman mengenai bagaimana penyandang oligodaktili 
memaknai dirinya dan kemudian membangun makna mengenai orang lain di sekitarnya.

Interpretasi subjektif muncul akibat interaksi dilakukan penyandang oligodaktili dengan lingkungan di sekitarnya. Berger dan Lukmann (Sulaeman \& Irta, 2017) mengungkapkan masyarakat sebagai kenyataan subjektif, menyiratkan suatu realitas objektif dimaknai secara subjektif individu. Interpretasi subjektif penyandang oligodaktili mengenai dirinya akan berbedabeda tergantung interaksi dan komunikasi yang dilakukannya. Mengingat interpretasi adalah proses aktif pikiran dan tindakan kreatif dalam menglarifikasi pengalaman pribadi (Littlejohn, 2009).

Melalui interaksi dan komunikasi dengan orang lain, individu berpikir untuk memodifikasi dan memberi makna atau mengubah makna berdasarkan interpretasi atas situasi dihadapi (Ritzer dalam Mulyana, 2018). Pembentukan makna merupakan proses produksi di mana penyandang oligodaktili berusaha memahami sesuatu dan menyampaikannya kepada orang lain yang dilandasi pengalaman sebagai bagian dari keseharian mereka dalam proses sosial.

\section{Teoretis Tindakan Sosial}

Penelitian ini menggunakan teori tindakan sosial, fenomenologi, dan interaksi simbolik. Teori tindakan sosial dicetuskan Max Weber (1864-1920) dan teori fenomenologi dari Alfred Schutz (18991959). Kedua teori ini digunakan untuk menganalisis realitas tindakan dirasakan dan dialami penyandang oligodaktili dengan keterbatasan jemari tangan dan jemari kaki dalam membentuk makna dirinya. Tindakan berhubungan dengan makna diri diinterpretasikan oleh teori tindakan sosial. Teori ini menekankan pada makna subjektif yang terjadi di dalam diri penyandang oligodaktili. Weber dalam Mulyana (2001) mendefinisikan tindakan manusia ketika dan sejauh individu memberikan suatu makna subjektif terhadap perilaku tersebut.

Pernyataan Weber memberikan gambaran bahwa semua tindakan yang diungkapkan penyandang oligodaktili berinteraksi dengan lingkungan di sekitarnya dengan memberikan makna subjektif. Tindakan ini terjadi selama mencerminkan makna subjektif. Jika demikian, tindakan adalah tindakan sosial yang dapat dijelaskan penyandang oligodaktili setelah mempertimbangkan persepsi orang lain. Dalam konteks ini, teori tindakan sosial merupakan salah satu teori berhubungan dengan tindakan orang lain.

Selanjutnya Weber dalam Mulyana (2018) mengatakan bahwa tindakan sosial berdasarkan makna subjektif diberikan oleh individu dan selama itu menganggap tindakan orang lain itu diwujudkan dalam penampilan mereka. Dengan demikian, penyandang oligodaktili melakukan tindakan dengan orang lain di lingkungan sekitarnya berdasarkan pemahaman, pemaknaan, dan interpretasinya terhadap tindakan orang lain. Tindakan penyandang oligodaktili merupakan keragaman tindakan melalui interaksi untuk memperoleh pengalaman dengan menginterpretasi setiap tindakan, dengan cara berkomunikasi satu sama lain yang sesuai dengan tujuan komunikasinya.

\section{Fenomenologi}

Teori lain yang digunakan dalam penelitian ini adalah teori fenomenologis dari Schutz yang membahas makna subjektif. Dalam perspektif Schutz (Mulyana, 2018), tugas utama dari analisis fenomenologis adalah merekonstruksi dunia kehidupan manusia "sebenarnya" dalam bentuk yang mereka alami sendiri. Untuk tujuan ini, pandangan fenomenologi merupakan penerapan untuk menggambarkan makna diri penyandang oligodaktili dengan keterbatasan jemari tangan dan jemari kaki berbeda dengan orang lain. Penelitian ini memberikan pengalaman dan pengetahuan penyandang oligodaktili untuk mengekspresikan pandangannya melalui interaksi dan komunikasi dengan orang lain. Ekspresi pandangan oligodaktili berdasarkan interpretasi subjektif mengenai pengalaman yang dialami dalam kehidupan kesehariannya. Menurut Kuswarno (2009), fenomenologi bertujuan untuk mempelajari bagaimana fenomena yang dialami orang, 
misalnya tindakan sosial pada pengalaman, makna, dan kesadaran.

Teori fenomenologis dianggap sebagai varian dari teori tindakan sosial. Teori fenomenologis dari Schutz berpengaruh di Eropa, masih di bawah payung teori tindakan sosial (Mulyana, 2018). Teori fenomenologi dan tindakan sosial terfokus pada makna subjektif individu. Karena itu, Schutz dalam Mulyana (2018) menjelaskan realitas dunia bersifat intersubjektif dalam arti bahwa anggota masyarakat berbagi persepsi dasar mengenai dunia yang mereka internalisasikan melalui sosialisasi dan memungkinkan mereka melakukan interaksi atau komunikasi. Tindakan penyandang oligodaktili adalah bagian dari posisinya di lingkungan sekitarnya, sehingga tindakan mereka itu bisa hanya merupakan kamuflase atau peniruan dari tindakan orang lain yang ada di lingkungannya.

\section{Interaksi Simbolik}

Weber menunjukkan bahwa untuk memperoleh pemahaman mengenai makna subjektif dari tindakan sosial bukan hanya menyajikan pemahaman mengenai motif individu sendiri tetapi memberikan empati melalui proses interaksi simbolik. Esensi dari teori interaksi simbolik akan membantu menjelaskan bagaimana penyandang oligodaktili yang melihat dirinya di saat berinteraksi dengan orang lain di lingkungan sekitarnya. Teori ini juga menjelaskan bagaimana penyandang oligodaktili bertindak berdasarkan pandangannya sendiri dan pandangan orang lain di lingkungannya mengenai dirinya dalam kaitannya dengan orang-orang di lingkungan sekitarnya.

Mulyana (2018) lebih lanjut menyatakan bahwa perspektif interaksi simbolik sebenarnya berada di bawah payung perspektif lebih besar, sering disebut perspektif fenomenologis atau perspektif interpretatif. Kaitannya dengan penyandang oligodaktili yang mengacu pada teori interaksi simbolik, tindakan penyandang oligodaktili atas dasar makna atau simbol fisik dan bentuk organ fisik. Makna simbol diperoleh melalui proses interaksi dengan orang lain. Penyandang oligodaktili mengubah makna simbol dimiliki berdasarkan interpretasi diri mereka sendiri.

Pada dasarnya teori interaksi simbolik menjelaskan bagaimana makna simbol kelainan fisik dan bentuk organ fisik. Simbol makna diri dimiliki dan dipahami melalui hasil interaksi antara penyandang oligodaktili dan orang normal di lingkungan sekitarnya atau antara sesama penyandang oligodaktili, atau dengan kelompok masyarakat lainnya. Simbol-simbol diciptakan, dipikirkan, dan dipahami oleh mereka adalah bahasa yang mengikat tindakan di antara mereka dan orang lain di luar dunia mereka.

\section{METODE PENELITIAN}

Fenomenologi komunikasi meupakan studi yang berupaya mengungkapkan realitas berdasarkan kesadaran yang dilandasi oleh pengalaman melalui komunikasi dan interaksi penyandang oligodaktili di lingkungan sekitarnya. Penelitian ini merujuk pada pernyataan "... phenomenologists explore the structures of consciousness in human experience" Creswell dalam Sulaeman (2017) dengan pendekatan kualitatif interpretatif subjektif, menitikberatkan pada pengamatan dan suasana alamiah.

Penelitian ini menggunakan pendekatan penelitian kualitatif (Sulaeman, 2018) pada perspektif interpretatif subjektif untuk menemukan dan menjelaskan mengenai makna diri penyandang oligodaktili.

Subjek pada penelitian ini adalah penyandang oligodaktili di Kampung Ulutaue Kabupaten Bone Provinsi Sulawesi Selatan. Terpilihnya subjek penelitian dengan pertimbangan bahwa merekalah dianggap memiliki karakteristik penting dan mengetahui informasi yang akan diteliti sebagaimana tergambar pada Tabel 2.

Teknik pengumpulan data yang digunakan adalah wawancara mendalam, pengamatan partisipan, dan studi pustaka. Dalam penelitian ini, peneliti menggunakan wawancara terstruktur. Peneliti melakukan pengamatan untuk 
mengungkapkan makna diri subjek di saat melakukan wawancara. Peneliti juga memasuki dunia kehidupan mengenai apa yang dialaminya dengan tujuan untuk melihat tindakan dan perubahan yang terjadi pada subjek dalam hubungan pemaknaan dirinya berbeda dengan orang lain. Selain itu, peneliti melakukan pengamatan jarak jauh dengan tujuan agar keberadaan peneliti tidak diketahui. Hasil pengumpulan data yang diperoleh selanjutnya dianalisis melalui alur kegiatan pengolahan data kualitatif dilakukan secara bersamaan yaitu reduksi data, penyajian data, penarikan simpulan, dan verifikasi dilakukan peneliti melalui interpretasi data sesuai konteks pertanyaan penelitian serta dihubungkan tujuan penelitian.

Tabel 2

Identifikasi Subjek Penelitian

\begin{tabular}{|c|c|c|c|c|c|c|c|}
\hline No. & Nama & Usia/Tahun & Jenis & Pendi & likan & Pekerjaan & Status \\
\hline 1. & Ambo Asse & 78 & Laki-laki & $\begin{array}{l}\text { Tidak } \\
\text { sekolah }\end{array}$ & pernah & Tidak ada & Menikah \\
\hline 2. & Kaharuddin & 52 & Laki-laki & Sekolah D & isar & Nelayan & Menikah \\
\hline 3. & Gambur & 32 & Laki-laki & $\begin{array}{l}\text { Tidak } \\
\text { sekolah }\end{array}$ & pernah & Nelayan & Belum menikah \\
\hline 4. & Ulhadi & 38 & Laki-laki & $\begin{array}{l}\text { Tidak } \\
\text { sekolah }\end{array}$ & pernah & Peternak sapi & Belum menikah \\
\hline 5. & Cahaya & 56 & Perempuan & $\begin{array}{l}\text { Tidak } \\
\text { sekolah }\end{array}$ & pernah & Pemulung laut & Menikah \\
\hline 6. & Hafid & 23 & Laki-laki & $\begin{array}{l}\text { Perguruan } \\
\text { (S1) }\end{array}$ & Tinggi & Mahasiswa & Belum menikah \\
\hline 7. & Abditiro & 40 & Laki-laki & $\begin{array}{l}\text { Tidak } \\
\text { sekolah }\end{array}$ & pernah & $\begin{array}{l}\text { Petani pekerja } \\
\text { tambak }\end{array}$ & Belum menikah \\
\hline 8. & Matahari & 35 & Perempuan & $\begin{array}{l}\text { Tidak } \\
\text { sekolah }\end{array}$ & pernah & Pemulung laut & Menikah \\
\hline 9. & Antokaseng & 15 & Laki-laki & $\begin{array}{l}\text { Tidak } \\
\text { sekolah }\end{array}$ & pernah & Peternak sapi & Belum menikah \\
\hline 10. & Nahriah & 32 & Perempuan & $\begin{array}{l}\text { Tidak } \\
\text { sekolah }\end{array}$ & pernah & Pemulung laut & Menikah \\
\hline 11. & Renita & 40 & Perempuan & $\begin{array}{l}\text { Tidak } \\
\text { sekolah }\end{array}$ & pernah & Nelayan & Belum menikah \\
\hline 12. & Ihwanullah & 15 & Laki-laki & $\begin{array}{l}\text { Tidak } \\
\text { sekolah }\end{array}$ & pernah & Pemulung laut & Belum menikah \\
\hline 13. & Subaco & 18 & Laki-laki & $\begin{array}{l}\text { Sekolah } \\
\text { Pertama }\end{array}$ & Lanjutan & Pelajar & Belum menikah \\
\hline 14. & Rahmat & 15 & Laki-laki & $\begin{array}{l}\text { Sekolah } \\
\text { Pertama }\end{array}$ & Lanjutan & Pelajar & Belum menikah \\
\hline 15. & Nurhalijah & 18 & Perempuan & $\begin{array}{l}\text { Sekolah } \\
\text { Pertama }\end{array}$ & Lanjutan & Pelajar & Belum menikah \\
\hline
\end{tabular}

Sumber: Hasil Pengumpulan Data, Desember 2017 - April 2018

\section{HASIL PENELITIAN DAN PEMBAHASAN}

Berdasarkan pandangan dan pengalaman dari 15 penyandang oligodaktili yang dijadikan subjek penelitian ini, menunjukkan bahwa makna diri penyandang oligodaktili terbentuk berdasarkan hasil pengalaman dan pengetahuan dimiliki melalui komunikasi pada interaksi sosial di lingkungan sekitarnya. Penyandang oligodaktili akan merasa diri sebagai "seperti apapun," menjadi landasan bagi pemunculan makna subjektif dari setiap tindakan dalam mengontruksi dirinya memiliki kelainan fisik dan bentuk organ fisik.

\section{Makna Diri Kelainan Fisik}

Pemaknaan diri yang dikemukakan subjek tidak terlepas dari pengalaman dan pengetahuan yang dimiliki dalam kehidupannya sebagai individu yang memiliki kelainan fisik dengan kategori diri pasrah, semangat, optimis, putus asa, tertutup, dan malas. 
Tabel 3

Makna Diri sebagai Penyandang Oligodaktili

\begin{tabular}{lll}
\hline No. & \multicolumn{1}{c}{ Makna Diri } & \multicolumn{1}{c}{ Karakteristik Kelainan Fisik Sebagai Penyandang Oligodaktili } \\
\hline 1. & Pasrah: & Kehendak Allah SWT yang sudah terjadi sebagai takdir. \\
& Penerimaan Diri & Ujian atau cobaan yang harus diterima, disyukuri dengan keikhlasan hati. \\
& Tidak berbanding dengan kenikmatan telah diberikan-Nya.
\end{tabular}

2. Semangat:

Menjalani Kehidupan

3. Optimis:

Diri Ideal

4. Putus Asa:

Tidak

Pengharapan

\section{Tertutup:}

Penghindaran Berinteraksi

pada Lingkungan
Introspeksi diri dan tidak berdiam diri, bukan sebagai penghambat hidup, semangat hidup, membantu aktivitas keluarga.

Berjuang pantang menyerah dan tidak menyesali hidup dalam kondisi kekurangan fisik yang dialami dalam melakoni aktivitas kehidupan.

Kesulitan yang dihadapi pasti mampu diatasi dan tidak mudah menyerah.

Keinginan bunuh diri, terhina, patah semangat, tidak tahan hidup, bosan hidup Memiliki sebagai individu yang mengalami kelainan fisik.

Menyesali diri sendiri serta menyakitkan hati, patah semangat, tidak percaya diri, menjijikkan, dan tidak ada harga diri sebagai penyandang oligodaktili.

Bersembunyi, mengurung diri, cuek, minder, takut dengan keadaan kelainan fisik dialami untuk tidak melakukan interaksi dengan lingkungan di sekitarnya.

Selalu tertekan, menyesali diri terus-menerus, tidak memiliki pengharapan masa depan, dan gairah hidup tidak ada untuk bekerja.

6. Malas:

Ketidakpastian Hidup

Sumber: Hasil Wawancara dan Pengamatan Peneliti, Desember 2017 - April 2018

Penyandang oligodaktili menerima dirinya akan kelainan fisik yang dialami. Penerimaan diri merupakan kehendak Allah SWT, ujian atau cobaan yang harus diterima, disyukuri dengan keikhlasan hati, dan tidak berbanding dengan kenikmatan telah diberikan-Nya.

Penyandang oligodaktili menggambarkan, semangat hidup pantang menyerah. Tidak mengherankan apabila memaknai kelainan fisik dari sudut pandang diri "optimis" dalam konteks "diri ideal" dengan pemahaman sebagai pengharapan akan kemampuan mengenai potensi dan kekurangan dirinya. Tidak semua penyandang oligodaktili memiliki sikap pengharapan, namun informan lainnya tetap eksis dan mampu mengenali potensi serta kekurangan dimilikinya. Diri memiliki kelainan fisik, ditemukan kategori makna diri optimis. Memiliki sikap pengharapan, tetap eksis, dan mampu mengenali potensi diri. Ataukah pengharapan bagi dirinya sendiri sebagai individu.

Kelainan fisik bukanlah sesuatu yang diinginkan, apalagi harus diderita seumur hidup, sampai saat ini belum ada solusi yang diberikan secara medis. Kelainan fisik yang dimaknai diri "putus asa" dengan "tidak memiliki pengharapan" akan kemampuan dirinya untuk tetap semangat menghadapi hidup yang penuh cobaan, karena hidup itu adalah anugerah yang harus tetap disyukuri.

Ketertutupan diri sebagai "penghindaran" melakukan tindakan komunikasi dengan lingkungan di sekitarnya. Berpikiran negatif serta menganggap orang lain akan menghina dan mengejek diri ketika berinteraksi. Jika berkomunikasi dengan lingkungan, cenderung menutup diri, kurang kepercayaan diri. Kondisi ini akan berimplikasi pada terhambatnya interaksi dengan orang lain dan selalu berpikiran negatif serta menganggap orang baru yang masuk di kampung akan menghina dan mengejek mereka jika bertemu. Dirinya beranggapan, bahwa orang yang tidak dikenal mau menemuinya. Mereka juga beranggapan bahwa orang lain akan menertawakan, mengejek, dan menghina keadaan fisiknya.

\section{Makna Diri Bentuk Organ Fisik}

Bentuk organ fisik penyandang oligodaktili ditandai dengan (1) Tiga jemari 
tangan dan jemari kaki; (2) Empat jemari tangan dan jemari kaki normal; (3) Empat jemari tangan dan jemari kaki kiri, jemari tangan dan jemari kaki kanan normal; (4) Empat jemari tangan kanan, tiga jemari kaki dan jemari tangan kiri normal; (5) Empat jemari tangan kanan, jemari tangan kiri dan kaki normal; (6) Tiga jemari tangan dan dua jemari kaki. Bentuk organ fisik ini dimiliki sejak lahir dan memandang dirinya tidak sama seperti organ fisik penyandang cacat lain pada umumnya, memaknai dirinya menimbulkan rasa malu, pantas dikasihani, kemauan kerja keras, sabar, dan pendorong semangat.

Tabel 4

Makna Diri Berdasarkan Bentuk Organ Fisik bagi Penyandang Oligodaktili

\begin{tabular}{lll}
\hline No. & \multicolumn{1}{c}{ Makna Diri } & \multicolumn{1}{c}{ Karakteristik Bentuk Organ Fisik pada Jemari } \\
Tangan dan atau Jemari Kaki
\end{tabular}

2. Pantas Dikasihani: Keprihatinan

3. Kemauan Kerja Keras: Menjalani Kehidupan

4. Sabar:

Penyerahan Diri
Memperoleh stigmatisasi sebagai tindakan diskriminasi pada pekerjaan yang dianggap menjijikkan.

Mendapatkan stigmatisasi sebagai tindakan penyangkalan keturunan Ketidakmampuan ekonomi.

Semangat hidup, dan pengharapan penghidupan masa akan datang lebih baik. Kemampuan menghargai diri sebagai sebuah keharusan pemenuhan hidup.

Kepasrahan, Kehendak Allah SWT.

Pengharapan menghadapi kehidupan masa akan datang.

Mendapatkan stigmatisasi sebagai tindakan penjulukan yang menjadi takdir dari Allah SWT.

5. Pendorong Semangat: Penerimaan sebagai dukungan keluarga dan bukan sebagai penghambat Pengharapan Pemakluman yang dianggap tidak ada perbedaan

Sumber: Hasil Wawancara dan Pengamatan Peneliti, Desember 2017 - April 2018

Bentuk organ fisik dengan diri menimbulkan perasaan malu dan ketidaknyamanan dalam menjalani kehidupan, mereka selalu menggunakan "sandal terompa" untuk menutupi jemari kakinya. Perasaan malu berpengaruh pada pergaulannya dan pembinaan hubungannya dengan orang lain. Kondisi ini secara langsung akan memicu terhadap interaksi dan komunikasi dengan orang lain, sehingga interaksi dan komunikasi dengan orang lain menjadi sangat terbatas.

Penyandang oligodaktili merasakan dirinya pantas dikasihani, hal tersebut diperlihatkan dengan bentuk organ fisik yang berbeda dengan orang lain. Dirinya menerima stigma perlakuan keluarga dan masyarakat atas dirinya. Di antara mereka tidak pernah menempuh pendidikan formal. Hal tersebut dipengaruhi oleh beberapa faktor di antaranya adalah ketidakmanpuan ekonomi keluarga, tidak adanya dukungan keluarga untuk pendidikan, dan perasaan malu, minder memiliki bentuk organ fisik berbeda dengan orang lain, kesemuanya memicu pada ketidakmampuan untuk membaca dan berhitung.

Bagi penyandang oligodaktili, keterbatasan bentuk organ fisik dimaknai pada diri "kemauan kerja keras" dalam "menjalani kehidupan" pantang menyerah dengan memperlihatkan integritas semangat hidup untuk menghidupi anggota keluarganya, supaya memiliki pengharapan kehidupan di masa mendatang yang lebih baik. Gambaran diri memiliki semangat hidup untuk tidak menyerah dengan keterbatasan bentuk organ fisiknya menjadikan diri menjalani kehidupan dengan tanggungjawab untuk memberikan penghidupan dasar pada dirinya dan keluarganya. 
Penyandang oligodaktili dengan menerima bentuk organ fisik berbeda dengan orang lain akan memiliki pengharapan kepada Allah SWT, harapan akan masa akan datang menjadi lebih baik sehingga memiliki harapan penghidupan akan lebih baik. Perlakuan masyarakat di lingkungan mereka terhadap bentuk organ fisik yang diidentikkan "manusia jemari tangan dan atau kaki yang nakal", menjadikan mereka menjaga jarak dengan lingkungan sekitarnya, namun mereka tetap pasrah dan menyakini dengan harapan bahwa keadaan ini akan mendorong dirinya lebih bersemangat dalam menjalani kehidupan.

Bentuk organ fisik ternyata tidak dimaknai negatif, namun dimaknai sebagai "pendorong semangat" mengandung konteks "pengharapan" hidup di masa yang akan datang. Mereka memiliki kelompok rujukan yang menerima dirinya sebagai dukungan dan bukan sebagai penghambat untuk memiliki "harapan" hidup di masa yang akan datang. Dengan kemampuan yang dimiliki dan dengan menampilkan dirinya sesuai dengan kelompok rujukan dalam melakukan interaksi mereka tidak merasa malu dan tidak membatasi diri untuk beraktivitas. Harapan untuk tetap bertahan hidup tercermin dari cita-citanya, yakni untuk tetap menimba ilmu atau menempuh pendidikan formal setinggi mungkin.

\section{Makna Diri Kelainan Fisik}

Penyandang oligodaktili menerima diri akan kelainan fisik dialami. Sebagai individu tentu mereka ingin memiliki fisik sempurna dan bukan sebagai individu dengan keterbatasan fisik. Pengungkapan ini sejalan hasil studi (Hadisiwi, 2011), "Diri sakit pasrah dialami penyandang filariasis dengan menerima keadaan sakitnya. ... berpengaruh terhadap perkembangan dirinya yang tidak optimal, kondisi sakitnya membuat mereka pasrah." Penerimaan diri apa adanya, bukan kehendak penyandang oligodaktili, namun merupakan ujian dan cobaan sebagai takdir, disyukuri dengan keikhlasan hati, karena tidak berbanding dengan kenikmatan yang telah diberikanNya.

Penerimaan diri apa adanya bukan berarti dirinya tidak pernah merasa kecewa memiliki kelainan fisik. Fromm mengatakan "Cinta pada diri sendiri adalah prasyarat untuk dapat mencintai orang lain" (Calhoun, J.F \& Joan, 1995), dengan menerima diri sendiri dapat juga menerima orang lain. Sebagai manusia mereka juga ingin memiliki fisik sempurna dan bukan sebagai individu dengan keterbatasan fisik, namun mereka tidak berusaha untuk mencari pengobatan, karena dirinya merasa malu akan dihina, ditertawakan, dan diejek.

Mereka menjalani proses kehidupan seperti orang lain, tetap berkomunikasi dan berinteraksi dengan cara membina hubungan baik dengan masyarakat di lingkungannya. Menjalani kehidupan dengan introspeksi, tidak berdiam diri, tidak menghambat hidup, tetap semangat hidup, membantu aktivitas keluarga, berjuang pantang menyerah, tidak menyesali diri hal tersebut senada dengan pernyataan, "Kebutuhan utama kita sebagai manusia, dan untuk menjadi manusia yang sehat secara rohaniah, adalah kebutuhan akan hubungan sosial yang ramah, hanya dapat terpenuhi dengan membina yang baik dengan orang lain" (Mulyana, 2015).

Tidak mengherankan jika penyandang oligodaktili tetap optimis. Pengharapan diriideal dengan penyandang oligodaktili sebagai pengharapan hidup di masa akan datang sebagaimana dikemukakan Harre mengenai pemaknaan diri terbentuk melalui perantara "... diri sendiri berhubungan dengan kejadian masa depan. Perantara akan terlihat ketika individu melakukan aktivitas. ... kemampuan individu, kemungkinan apa yang ada untuk masa depan" (Littlejohn, 2009). Memiliki pengharapan berarti memiliki kemampuan mengenali potensi dirinya dalam mengatasi kesulitan hidup, tidak mudah menyerah, dan memiliki kepercayaan diri serta tidak takut akan kelainan fisik yang dialami.

Jika penyandang oligodaktili berkomunikasi dengan lingkungan, cenderung menutup diri, kepercayaan diri kurang sehat, seperti dikemukakan (Maltz, 1970) "Untuk meningkatkan kepercayaan diri, menumbuhkan cara pandang yang sehat menjadi perlu" memunculkan diri menghindar, seperti bersembunyi, mengurung diri, cuek, minder, takut akan keadaan kelainan fisik dialami. Ketertutupan diri 
memunculkan diri pendiam, emosional, penyendiri, minder, pemalu terhadap orang lain, seperti ditertawakan, di ejek, di hina akan kelainan fisiknya.

Pengalaman yang dialami dengan ketidakpastian hidup di masa yang akan datang sejalan dengan pernyataan (Syam, 2012) “... pola asuh yang keliru dan negatif, atau lingkungan kurang mendukung, cenderung mempunyai cara pandang negatif ...". Ketidakmampuan mengatasi diri dipengaruhi oleh lingkungan, seperti pola asuh orang tua mengabaikan dan kurang perhatian, suka marah dan melecehkan penyandang oligodaktili. Pola asuh yang diberikan kurang mendukung dan cenderung memberikan pemaknaan negatif sebagai individu "tidak berguna dan tidak memiliki harapan hidup di masa depan," seperti kisah dituturkan Alex Phiri (Coleridge, 1997), tokoh panutan pergerakan penyandang cacat di Zimbabwe dan Afrika bagian selatan. Sejak berumur sepuluh tahun ditinggalkan begitu saja keluarganya di sebuah rumah sakit di saat mengalami kehilangan kedua kaki.

Semakin banyak pengalaman dan pengetahuan yang dipandang dari sudut tertentu, maka semakin dalam pemaknaan kelainan fisik digunakan melalui sudut pandang tersebut, seperti hasil studi dilakukan (Musgrove, 1977) mengenai para penghuni tempat perawatan kaum difabel di Leonard Cheshire Home, disebutkan bahwa "Peristiwa di masa lalu yang mendalam dan terpatri kuat dalam ingatan memengaruhi pemaknaan akan sesuatu di masa kini." Sesungguhnya, makna kelainan fisik akan berubah seiring perkembangan pengalaman penyandang oligodaktili mengenai elemen yang menjadi bagian konstruksi makna. Pemaknaan dimiliki penyandang oligodaktili sebagai “... the heart of perceiving, remembering, judging, feeling, and thinking...when we reflect upon something and arrive at its essence, we have discovered another major component of meaning" (Sulaeman \& Muh, 2015). Disebutkan pula bahwa: “... without meaning we would not make choises, because the concept of choice would not be available to us" (Lindlof, 1995). Makna penyandang oligodaktili dibentuk dari penilaian dan tindakan diri mereka yang memiliki kelainan fisik pada jemari tangan dan atau jemari kaki sejak lahir.

Makna diri dibangun melalui komunikasi dengan lingkungan sekitarnya. Jika menggunakan pandangan Cooley mengenai makna diri kelainan fisik pada jemari tangan dan atau jemari kaki, maka akan mempermudah pemahaman mengenai bagaimana penyandang oligodaktili menetapkan makna dirinya dan kemudian membangun makna mengenai orang lain di sekitarnya. Makna dibangun penyandang oligodaktili mengenai orang-orang, aturan, nilai-nilai dan prinsip kelainan fisik dialami sangat ditentukan oleh proses komunikasi dibangun mengenai diri memiliki kelainan fisik.

Melalui komunikasi dengan lingkungan di sekitarnya, individu berpikir untuk memodifikasi dan memberi makna atau mengubah makna berdasarkan interpretasi atas situasi dihadapi Ritzer dalam Mulyana (2018)). Pembentukan makna diri kelainan fisik merupakan proses produksi penyandang oligodaktili berusaha memahami sesuatu dan menyampaikannya kepada orang lain yang dilandasi pengalaman sebagai bagian dari keseharian mereka dalam proses sosial.

\section{Makna Diri Bentuk Organ Fisik}

Makna diri bentuk organ fisik penyandang oligodaktili sejak lahir, seperti diri menimbulkan rasa malu, diri pantas dikasihani, diri kemauan kerja keras, diri sabar, dan diri pendorong semangat.

Perasaan malu yang dirasakan penyandang oligodaktili dengan bentuk organ fisik yang berbeda dengan orang lain berdampak pada aktivitas mereka di lingkungan sekitarnya, seperti pernyataan "... membayangkan diri dari pandangan orang lain" (West \& Turner, 2007), memandang diri sendiri melalui kemampuan mengambil peran, seperti memakai "sandal terompa" untuk menutupi jemari kaki yang berbeda dengan jemari kaki orang lain, mengindikasikan penampilan dirinya yang merujuk pada Cooley dengan konsep "the looking-glass self" yaitu "Kemampuan melihat diri melalui pantulan dari padangan orang lain" (Mulyana, 2018). Penyandang oligodaktili memiliki kemampuan untuk 
membayangkan penilaian orang lain, seperti menjijikkan dan menakutkan jemari kaki yang akhirnya menutupi dengan sandal terompa.

Penyandang oligodaktili menerima
perlakuan stigma sebagai tindakan diskriminasi pada pekerjaan mereka dianggap menjijikan. Perlakuan ini senada dengan ungkapan (Goffman, 1973) "Stigma seringkali dimunculkan dalam kelainan kulit dan penyandang cacat fisik," penerimaan stigma sebagai penyangkalan dan penolakan bagi dirinya yang memicu adanya diskriminasi keturunan dan lapangan kerja yang perlu diberikan perhatian secara keprihatinan yang sejalan pernyataan “... beberapa diskriminasi institusional dalam sistem sosial terjadi perlakuan yang kurang adil terhadap kelompok masyarakat tertentu, misalnya adanya pekerjaan tertentu yang sulit dimasuki" (Eitzen, 1986). Diskriminasi yang diterima memunculkan kecemasan sosial dan hambatan dalam berkomunikasi, seperti menarik diri pada lingkungan, perasaan tertekan, pendiam, dan muncul sikap negatif memandang orang lain.

Bagi penyandang oligodaktili, keterbatasan bentuk organ fisik yang dimiliki berbeda dengan orang lain di lingkungan sekitarnya merupakan “... kecacatan akan membuat dirinya lebih kuat dan atau pekerja keras ... memiliki motivasi diri dan selalu berusaha untuk menjadi lebih kuat" (Gilson, C \& Stacy, 2011). Semangat hidup ini mencerminkan diri optimis, penuh percaya diri dan selalu bersikap positif terhadap segala sesuatu (Syam, 2012). Memiliki semangat hidup tidak menyerah dengan kemampuan menghargai dirinya, sebuah keharusan dijalani sebagai pemenuhan kebutuhan dasar keluarga dengan semangat hidup bekerja.

Bentuk organ fisik dialami bukan kehendak dirinya, semuanya sudah takdir dari Allah SWT, walaupun menerima stigma sebagai penjulukan negatif "jari nakal" identik dengan keterbatasan organ fisik. Tindakan tersebut senada dikemukakan (Goffman, 1973) "Stigmatisasi bagi penyandang cacat berhubungan dengan cacat tubuh yang dimiliki individu." Stigma sebagai tindakan diskriminasi "pengusiran" untuk melakukan aktivitas bersama dengan orang lain.

Dengan pemahaman dan pemaknaan bentuk organ fisik dapat diketahui bahwa makna diri dibentuk oleh pengalaman dan pengetahuan dimiliki akan keterbatasan jemari kaki dan atau jemari kaki dialami yang dapat berubah seiring dengan proses perubahan ruang dan waktu yang sejalan dengan teori Cooley pada konsepnya "the looking-glass self' yaitu kemampuan melihat diri melalui pantulan dari pandangan orang lain.

Realitas sosial yang dialami ditandai dengan keterbatasan bentuk organ fisik sejak lahir, menumbuhkan interpretasi subjektif bagi mereka yang mengalaminya. Interpretasi subjektif muncul akibat interaksi yang dilakukan dengan lingkungan di sekitarnya. Light, Berger \& Luckmann (1967) mengungkapkan bahwa masyarakat sebagai kenyataan subjektif yang menyiratkan suatu realitas objektif dimaknai secara subjektif oleh individu. Interpretasi subjektif penyandang oligodaktili mengenai dirinya akan berbeda-beda tergantung pada komunikasi dilakukannya. Mengingat interpretasi adalah proses aktif pikiran dan tindakan kreatif dalam mengklarifikasi pengalaman pribadi (Littlejohn, 2009).

Makna diri penyandang oligodaktili memiliki kelainan fisik dan bentuk organ fisik sejak lahir yang berbeda dengan orang lain di lingkungan sekitarnya, dimaknai berdasarkan kesadaran individu dengan pemaknaan diri secara subjektif. Dalam prinsip fenomenologi berarti ilmu pengetahuan yang tidak diketemukan pada pengalaman luar yang terlihat, namun lebih kepada kesadaran penyandang oligodaktili yang lebih bersifat subjektif, maka makna diri penyandang oligodaktili berasal dari pengalaman hidup mereka, sehingga makna diri akan diartikan berbeda-beda oleh setiap penyandang oligodaktili, tergantung dari pengalaman masing-masing mereka alami dalam kehidupan sehari-hari untuk dapat berubah dari waktu ke waktu. 


\section{PENUTUP}

\section{Simpulan}

Penyandang oligodaktili sebagai subjek penelitian telah mengonstruksi dirinya dengan makna diri yang memiliki kelainan fisik dan bentuk organ fisik yang berbeda dengan orang lain. Penyandang oligodaktili dapat memberikan makna tertentu mengenai apa yang dialami berdasarkan pengalaman komunikasi dalam interaksi sosial dalam kehidupan sehari-harinya telah membentuk dunia sosial yang diyakininya dan berkembang menjadi realitas dalam kehidupan sosial.

Beberapa temuan menjelaskan bahwa penyandang oligodaktili memiliki makna diri kelainan fisik dan keterbatasan bentuk organ fisik. Penyandang oligodaktili diperlakukan dengan cara berbeda dengan orang lain di lingkungan sekitarnya, meskipun sebagian besar dari mereka menunjukkan kecenderungan yang sama yaitu menghindarkan diri dari orang lain untuk melakukan komunikasi dalam interaksi sosial di lingkungan sekitarnya. Perlakuan penerimaan diskriminasi memunculkan kecemasan sosial dan hambatan komunikasi. Penelitian ini menemukan pesan-pesan positif yang cenderung diterima dan diinternalisasikan, seperti diri pasrah, diri semangat dan diri optimis sebagai makna diri positif dengan kepercayaan diri, tidak ada pembedaan, hidup seperti apa adanya, tidak terbebani dan tidak memikirkan kelainan fisik dialami. Kemudian bentuk organ fisik dimiliki berbeda dengan orang lain di lingkungan sekitarnya, sebagian dari mereka masih menyesali nasibnya, dan lainnya memaknai sebagai karunia Allah SWT di balik kelainan fisik dan bentuk organ fisik yang dialami.

\section{Saran}

Dari sisi metodologis, diharapkan penelitian ini dapat dilanjutkan dengan metode dan pendekatan penelitian yang sama, seperti metode fenomenologi dan pendekatan kualitatif untuk mengkaji perilaku komunikasi penyandang oligodaktili. Tujuannya adalah untuk mengeksplorasi bentuk-bentuk perilaku komunikasi penyandang oligodaktili dengan sesama penyandang oligodaktili, keluarga, masyarakat, pemerintah maupun media televisi.

Melalui penelitian ini diharapkan pihak terkait, terutama Kementerian Sosial, Kementerian Pendidikan dan Olahraga mendukung dan menyosialisasikan mengenai penyandang oligodaktili agar tidak ada lagi stigmatisasi sebagai tindakan diskriminasi dan penjulukan bagi penyandang oligodaktili.

\section{DAFTAR PUSTAKA}

Calhoun, J.F. \& Joan, R.. (1995) Psikologi Tentang Penyesuaian dan Hubungan Kemanusiaan (terjemahan R.S. Satmoko). Semarang, IKIP Semarang Press.

Coleridge, P. (1997) Pembebasan dan Pembangunan: Perjuangan Penyandang Cacat di Negara-Negara Berkembang. Yogyakarta, Pustaka Pelajar.

Eitzen, S.. (1986) Social Problems. Boston, Allyn and Bacon Inc.

Gabriella, E. A., Hanny H., \& Heru, R.B. (2018) Konstruksi Makna Kegiatan Traveling dan Teaching Komunitas 1000 Guru oleh Relawan. Jurnal Nomosleca. 04 (1), 655666.

Gabriella, E.A., Hanny H. \& Heru, R.B. (2018) Konstruksi Makna Kegiatan Traveling dan Teaching Komunitas 1000 Guru oleh Relawan. Jurnal Nomosleca. [Online] 04 (1), 655-666. Available from: http://jurnal.unmer.ac.id/index.php/n/article / view/1795 [accessed: 13 Februari 2018].

Gilson, C. \& Stacy, D. (2011) Constructions of Disability at a University in Hong Kong: Perspectives of Disabled Students, Staff Members, and Instructors. Journal Disability Studies Quarterly acknowledges and appreciates. [Online] 31 (2), 10415718. Available from: doi:10.18061/dsq.v31i2.1589[accessed: 15 Januari 2018].

Goffman, E. (1973) Stigma Notes on The Management of Spoiled Indentity. New Jersey, Prentice-Hall Inc.

Hadisiwi, P. (2011) Konstruksi Makna Penyandang Filariasis (Studi Fenomenologi Tentang Makna Penyandang Filariasis dalam Komunikasi Risiko Kesehatan di Kabupaten Bandung). Pascasarjana Universitas Padjadjaran. 
Hafiar, H. (2012) Cacat dan Prestasi Melalui Pengalaman Komunikasi Atlet Penyandang Cacat (Studi Fenomenologi Mengenai Konstruksi Makna Kecacatan dan Status Sebagai Atlet Berprestasi Melalui Pengalaman Komunikasi Atlet Penyandang Cacat Berprestasi di Bandung). Pascasarjana Universitas Padjadjaran.

Kuswarno, E. (2009) Fenomenologi. Bandung, Widya Padjadjaran.

Light, D.W., Berger, P.L. \& Luckmann, T. (1967) The Social Construction of Reality: A Treatise in the Sociology of Knowledge. [Online]. New York, Anchor Books. Available from: doi:10.2307/3710424.

Lindlof, T.R. (1995) Qualitative Communication Research Methods. California, Sage Publications.

Littlejohn, S. dan K.F. (2009) Teori-teori Komunikasi. Jakarta, Salemba Humanika.

Maltz, M. (1970) The Magic Power of Self-Image Psychology. New York, Pocket Books.

Marks, D.F; Michael, F; Brian, E. \& Carla, W. (2000) Health Psychology: Theory, Research and Practice. London, Sage.

Mulyana, D. \& Sulaeman. (2016) People with Lobster - Claw Syndrome: A Study of Oligodactyly Sufferers and their Communication Experiences in the Village of Ulutaue, South Sulawesi, Indonesia. Mediterranean Journal of Social Sciences MCSER Publishing, Rome-Italy. [Online] 7 (1), 136-144. Available from: doi:10.5901/mjss.2016. v7n1s1p136 [accessed: 20 Desember 2017].

Mulyana, D. (2015) Komunikasi Lintas Budaya (Pemikiran, Perjalanan, dan Khayalan). Edisi Revisi, Cet.III. Bandung, Remaja Rosdakarya.

Mulyana, D. (2018) Metodologi Penelitian Kualitatif: Paradigma Baru Ilmu Komunikasi dan Ilmu Sosial Lainnya. Cet.IX. Bandung, Remaja Rosdakarya.

Mulyana, D. (2001) Pengantar Ilmu Komunikasi. Bandung, Remaja Rosdakarya.

Musgrove, F. (1977) Margins of the Minds. London, Methuen.

Sulaeman, \& Muh, I.F.. (2015) Pengalaman Komunikasi Penyandang Oligodaktili di Kampung Ulutaue, Bone, Sulawesi Selatan. Jurnal Dakwah Media Komunikasi dan
Dakwah. [Online] 16 (1), 117-138. Available from: doi:10.14421/jd.2015.

Sulaeman, \& Muhammad, R. (2018) Environment Communication: Symbolic Meaning of Forest of Tribal Peoples of Naulu Central Moluccas. Journal The Social Sciences. [Online] 13 (5), 1006-1013. Available from: doi: $10.3923 /$ sscience.

Sulaeman. \& Irta, S. (2017) Motif Da'i Berdakwah di Kota Ambon. Afkaruna: Indonesian Interdisciplinary Journal of Islamic Studies. [Online] 13 (2), 240-264. Available from: doi:10.18196/AIIJIS.2017.0074 [accessed: 21 Januari 2018].

Sulaeman. \& Muh, I.F.. (2015) Pengalaman Komunikasi Penyandang Oligodaktili di Kampung Ulutaue, Bone, Sulawesi Selatan. Jurnal Dakwah Media Komunikasi dan Dakwah. [Online] 16 (1), 117-138. Available from: doi:10.18196/AIIJIS.2017.0074 [accessed: 21 Januari 2018].

Sulaeman. \& Muhammad, R. (2018) Environment Communication: Symbolic Meaning of Forest of Tribal Peoples of Naulu Central Moluccas. Journal The Social Sciences. [Online] 13 (3), 1006-1013. Available from: doi:10.3923/sscience [accessed: 04 April 2018].

Sulaeman (2018) Dramaturgi Penyandang Oligodaktili. Jurnal Aspikom. [Online] 03 (4), 662-674. Available from: doi:10.24329/aspikom.v3i4.270.

Sulaeman (2017) Jurnalis Perempuan Cet. I. Ambon, LP2M IAIN.

Syam, N.W. (2012) Psikologi Sosial Sebagai Akar Ilmu Komunikasi. Bandung, Simbiosa Rekatama Media.

Turnpenny, P.D., J.C.S. Dean, P. Duffty, J.A. Reid, and P.C. (1992) Weyer's Ulnar Ray/Oligodactyly Syndrome and the Association of Midline Malformations with Ulnar Ray Defects. Journal of Medical Genetics. [Online] 29 (9), 659-662. Available from: https://www.ncbi.nlm.nih.gov/ pmc/articles/PMC1016100/Diakses Tanggal 08 Januari 2018.

West, R. \& Turner, L.H. (2007) Teori Komunikasi: Analisis dan Aplikasi. 3rd edition. Jakarta, Salemba Humanika. 